\title{
ANALISIS EFISIENSI KINERJA LEMBAGA AMIL ZAKAT DI INDONESIA
}

\author{
Ayif Fathurrahman; Ibnu Hajar \\ Universitas Muhammadiyah Yogyakarta \\ e-mail: ayief_ospp@yahoo.com
}

\begin{abstract}
In the span of 74 years of Indonesia's independence, poverty, unemployment and social inequality remain major problems in national development. The Central Statistics Agency (BPS) recorded that as of March 2018, the number of poor people in Indonesia reached 25.95 million people or 9.82 percent of the total population of Indonesia. Seeing the problems that are so complex, it should be to pay attention to one solution in Islam to be able to prosper the community. Islam as rahmatan li al-'alamin has a solution through zakat, infaq and alms (ZIS) instruments. Zakat is one of the pillars of Islam consisting of shahadah, prayer, zakat, fasting and pilgrimage for those who are able. This study aims to analyze the level of efficiency of zakat management institutions in Indonesia in the period 2012-2016. The subjects in this study were the national zakat management organization with a purposive sampling technique. Of the $19 \mathrm{OPZs}$ listed in the Ministry of Finance, two OPZs are chosen, namely the Rumah Zakat and Dompet Dhuafa. Data collection techniques use documentation techniques. The object examined is the financial statements for the period 2012-2016. The method used is Data Envelopment Analysis (DEA) with the production approach, input-output orientation and CRS assumptions. The results of this study show relative efficiency. National zakat management organization namely Rumah Zakat with a production approach, input-output orientation and CRS assumptions have Efficiency with $100 \%$ annual score. In the production approach, input-output orientation and the assumption of CRS Dompet Dhuafa have been Efficient in the first 3 years, namely in 2012, 2013 and 2014. However, in 2015 there was efficiency with an efficiency score of $78.71 \%$ and in 2016 it was $64.33 \%$. Inefficiency occurs in the variable total assets, costs of socialization, collection and distribution of zakat.
\end{abstract}

Keywords: data envelopment analysis, efficiency, production approach, zakat management agency

\section{Pendahuluan}

Dalam rentang waktu 74 tahun Indonesia merdeka, kemiskinan, pengangguran dan kesenjangan sosial masih menjadi permasalahan utama dalam pembangunan nasional. Badan Pusat Statistik (BPS) mencatat per Maret 2018, jumlah penduduk miskin di Indonesia mencapai 25,95 juta orang atau 9,82 persen dari total penduduk Indonesia. ${ }^{1}$

Melihat permasalahan yang begitu komplek, sudah seharusnya untuk memperhatikan salah satu solusi dalam Islam untuk dapat mensejahterakan masyarakat. Islam sebagai rahmatan li al-'äamin memiliki solusi melalui instrumen zakat, infak dan sedekah (ZIS). ${ }^{2}$

\footnotetext{
${ }^{1}$ Badan Pusat Statistik (BPS), Persentase Penduduk Miskin di Indonesia 2018 (Jakarta Pusat: Badan Pusat Stastistik, 2018)

${ }^{2}$ Irfan Syauqi Beik, "Analisis Peran Zakat dalam Mengurangi Kemiskinan: Studi Kasus Dompet Dhuafa”, Jurnal Pemikiran dan Gagasan, Vol. II (2009), 1.
} 
Zakat adalah salah satu rukun Islam yang terdiri dari syahadat, shalat, zakat, puasa dan haji bagi yang mampu. Dalam al-Quran, menurut Yusuf Qardhawi, kedudukan menunaikan zakat bersamaan dengan kewajiban menunaikan shalat. ${ }^{3}$

Zakat merupakan stimulus dalam suatu perekonomian sehingga memunculkan kekuatan baru dalam penghimpunan investasi yang signifikan sehingga akan mendorong peningkatan produksi dalam siklus perekonomian suatu daerah. Bahkan secara makro zakat akan dapat meningkatkan agregat demand karena meningkatnya purchasing power (daya beli) masyarakat atas barang-barang dan jasa. ${ }^{4}$ Ketika zakat diimplementasikan secara sistem pengelolaan yang baik, dalam artian bahwa zakat adalah peraturan yang mengikat dalam diri setiap muslim dengan peran pemerintah sebagai regulator sekaligus badan amil zakatnya, maka secara pasti akan menyebabkan munculnya lapangan kerja yang sangat luas sehingga setiap warga negara mempunyai lahan pekerjaan dan otomatis akan terjadi migrasi pengangguran menjadi karyawan dalam jumlah yang sangat besar.

Indonesia sebagai negara yang memiliki penduduk muslim terbesar di dunia mempunyai potensi zakat yang cukup besar. Laporan BAZNAS pada 2019 menyebutkan bahwa terdapat 462 triliun rupiah potensi zakat yang ada di Indonesia pada tahun 2017, dan belum semuanya terserap secara optimal. ${ }^{5}$ Padahal zakat memiliki banyak manfaat. Manfaat zakat sebagai instrument people to people transfer seharusnya bisa menjadi jalan keluar terbaik untuk mengurangi ketimpangan dan kesenjangan ekonomi. ${ }^{6}$

Manfaat zakat dibuktikan dari penelitian Beik yang menyebutkan bahwa zakat mampu mengurangi jumlah keluarga miskin dari 84 persen menjadi 74 persen. Dari aspek kedalaman kemiskinan, zakat juga terbukti mampu mengurangi kesenjangan kemiskinan dan kesenjangan pendapatan dari Rp. 540.657,01 menjadi Rp. 410.337,06. Ditinjau dari tingkat keparahan kemiskinan, zakat juga mampu mengurangi tingkat keparahan kemiskinan yang ditandai dengan penurunan nilai Indeks Sen. Indeks Sen adalah indeks kemiskinan yang menggabungkan pendekatan head count ratio, income gap ratio, dan koefisien Gini sebagai indikator distribusi pendapatan di antara kelompok miskin. Indkes Sen mengalami penurunan dari 0,46 menjadi 0,33. Nilai indeks Foster, Green, and Thorbecke (FGT) yang menunjukkan tingkat keparahan kemiskinan turun nilainya dari 0,19 menjadi 0,11. Kajian ini menjadi bukti bahwa instrumen zakat memiliki potensi yang luar biasa. ${ }^{7}$

Meskipun potensi zakat di Indonesia termasuk yang cukup besar, namun realisasi penghimpunan zakat yang telah dijaring oleh anggota forum zakat (FOZ) tidak lebih dari 1\% dari potensi yang ada. Dana yang berhasil dihimpun dan disalurkan oleh organisasi pengelola zakat (OPZ) anggota FOZ terdapat pada tabel di bawah ini.

\footnotetext{
${ }^{3}$ Yusuf al-Qardhawi, Hukum Zakat (Bogor: Litera Antar Nusa, 1999), 231.

${ }^{4}$ Eko Suprayitno, "Pengaruh Zakat Terhadap Variabel Makro Ekonomi Indonesia: Studi Pada Perekonomian Indonesia Tahun 2000” (Tesis--Universitas Gadjah Mada Yogyakarta, 2004).

${ }^{5}$ Badan Amil Zakat Nasional, Outlook Zakat Indonesia 2019 (Jakarta: Pusat Kajian Strategis Baznas, 2019).

${ }^{6}$ Badan Amil Zakat Nasional, Outlook Zakat Indonesia 2017 (Jakarta: Pusat Kajian Strategis Baznas, 2016).

${ }^{7}$ Irfan Syauqi Beik, “Analisis Peran Zakat”, 9.
} 
Tabel 1.1. Perbandingan Potensi Zakat dan Realisasi Zakat

\begin{tabular}{|l|l|l|l|}
\hline Tahun & $\begin{array}{c}\text { Potensi Penerimaan } \\
\text { zakat* }\end{array}$ & \multicolumn{1}{|c|}{ Realisasi zakat** } & Presentase \\
\hline $\mathbf{2 0 1 1}$ & Rp. 58.961 .143 .222 .174 & Rp. 1.728 .864 .359 .398 & $2,93 \%$ \\
\hline $\mathbf{2 0 1 2}$ & Rp. 64.086 .440 .764 .997 & Rp. 2.212 .398 .951 .344 & $3,45 \%$ \\
\hline $\mathbf{2 0 1 3}$ & Rp. 69.794 .542 .095 .826 & Rp. 2.639 .604 .069 .729 & $3,78 \%$ \\
\hline $\mathbf{2 0 1 4}$ & Rp. 78.374 .957 .309 .348 & Rp. 3.300 .000 .000 .000 & $4,21 \%$ \\
\hline $\mathbf{2 0 1 5}$ & Rp. 82.609 .152 .671 .724 & Rp. 3.650 .369 .012 .964 & $4,42 \%$ \\
\hline $\mathbf{2 0 1 6}$ & Rp. 104.000 .000 .000 .000 & Rp. 3.738.216.792.496 & $3,59 \%$ \\
\hline
\end{tabular}

Sumber:* Fikriyah Canggih dan Yasin (2017), Wibisono (2016) ** Pusat Kajian dan Strategis (Puskas) BAZNAS (2016), Biro TI dan Pelaporan BAZNAS (2017)

Tabel di atas menggambarkan bahwa dari tahun 2011-2016 terus terjadi kesenjangan antara potensi zakat dengan realisasinya. Pada tahun 2015 potensi zakat yang ada di Indonesia sebesar Rp. 82,6 triliun namun yang terealisasi hanya Rp. 3,6 triliun. Begitu juga tahun 2016 potensi zakat yang terealisasi hanya Rp. 3,7 triliun dari Rp. 104 triliun atau 3,6 \% dari potensi tersebut. $^{8}$

Salah satu penyebab kesenjangan tersebut karena rendahnya kepercayaan masyarakat terhadap lembaga zakat. Riset yang dilakukan PIRAC menyatakan bahwa tingkat kepercayaan masyarakat terhadap lembaga amil zakat (LAZ) dan badan amil zakat (BAZ) masih sangat kecil. $^{9}$

Akan tetapi, besarnya potensi zakat ini belum dibarengi dengan pengoptimalan penghimpunan maupun pendistribusian. Sehingga untuk mengetahui sejauh mana lembaga amil zakat mampu menghimpun dan menyalurkan zakat, infak dan sedekah (ZIS) yang terhimpun perlu adanya standar tata kelola yang baik, di mana salah satu indikatornya adalah efisiensi dan efektifitas sebagai tolak ukur kinerja lembaga keuangan.

Setidaknya pengelolaan zakat menjadi dua bagian, yaitu lembaga yang dibentuk oleh pemerintah dan yang dibentuk oleh masyarakat (lembaga amil zakat/LAZ). Pengelolaan zakat sebagaimana yang disebut dalam UU RI No. 23 pasal 1 ayat 1, merupakan kegiatan, perencanaan, pelaksanaan dan pengawasan terhadap pengumpulan dan pendistribusian serta pendayagunaan zakat. ${ }^{10}$

Dalam perkembangannya banyak organisasi pengelola zakat bermunculan, namun organisasi pengelola zakat pada tingkat nasional yang diakui oleh Ditjen Pajak sebagai Pengurang Penghasilan Kena Pajak yang legal hanya ada 19 OPZ, antara lain Badan Amil Zakat Nasional, Dompet Dhuafa, Lazis Nahdlatul Ulama, LAZ Persis, Lazis Muhammadiyah, BMH Hidayatullah, LAZ LDII, PKPU, Rumah Zakat, LAZ BMM, LAZ BRI, Lazis Pertamina, LAZNAS BSM, LAZIS IPHI, BMT ICMI, Lazis Darut Tauhid, YDSF, BAMUIS

\footnotetext{
${ }^{8}$ Yusuf Wibisono, Potensi Zakat Nasional: Peluang dan Tantangan Pengelolaan (Jakarta: BAZNAS, 2016$), 59$.

9 Berdasarkan survey PIRAC menyatakan bahwa masyarakat masih menyalurkan zakatnya ke panitia penampung zakat sekitar tempat tinggal $63,6 \%$, masyarakat langsung menyalurkan dana zakat kepada yang berhak menerima sebesar 20\%, dan yang menyalurkan ke BAZ, LAZ, dan yayasan sosial sebesar $12,5 \%$. Lihat Ria Casmi Arrsa, "Peran Negara dalam Merevitalisasi Pengelolaan Zakat Sebagai Upaya Strategis Penanggulangan Kemiskinan di Indonesia”, www.legalitas.org.

${ }^{10}$ Nurul Bariyah, Total Quality Management Zakat (Jakarta: Wahana Kardofa FAI UMJ, 2012), 163.
} 
BNI, dan Lazis Takaful. ${ }^{11}$ Untuk mengetahui sejauh mana OPZ mampu menghimpun dan menyalurkan zakat, infak dan sedekah maka dibutuhkan alat ukur yang sesuai, salah satunya adalah efisiensi.

Suatu LAZ dapat dikatakan efektif dan efisien apabila program-program yang dicanangkan dapat berjalan dan berhasil mencapai tujuan perubahan sosial, yaitu masyarakat miskin yang berdaya, mempunyai pengetahuan dan kemampuan dalam memenuhi kebutuhan hidupnya baik yang bersifat fisik. ${ }^{12}$

Efisiensi adalah kemampuan menjalankan tugas dengan baik dan tepat dan dapat dijadikan alat ukur untuk membandingkan kinerja satu dengan yang lainya. ${ }^{13}$ Agar efisiensi suatu OPZ dapat diukur dan diketahui maka dibutuhkan laporan keuangan yang baik, maka dari itu OPZ berpedoman pada PSAK 109 tentang akuntansi zakat. Penerapan PSAK 109 menjadi bukti komitmen pengurus dalam mewujudkan tranparansi dan akuntabilitas pengelolaan dana ZIS. ${ }^{14}$

Lembaga zakat dapat dikatakan sehat, kredibel, efektif, dan efisien apabila memenuhi berbagai indikator-indikator, di antaranya pertama, tujuan dan kegiatan lembaga sesuai dengan kebutuhan masyarakat; kedua, program program yang dilakukan sejalan dengan misi dan rencana strategis; ketiga, mengalokasikan sumber daya yang cukup untuk memastikan bahwa setiap program bisa mencapai sasaran dan tujuannya. ${ }^{15}$

Dari penjelasan di atas, maka perlu dilakukan suatu penelitian untuk mengetahui efisiensi dari suatu organisasi pengelola zakat. Penelitian akan menggunakan metode Data Envelopment Analysis. Penelitian berfokus kepada organisasi pengelola zakat, yakni Dompet Dhuafa dan Rumah Zakat. Pemilihan kedua organisasi tersebut dikarenakan ketiganya merupakan organisasi yang konsisten dalam mempublikasikan laporan keuangannya dan keduanya memiliki kelebihan yang telah diakui oleh nasional dan internasional. Selain itu, pada tahun 2016 kedua lembaga tersebut telah mampu mengelola dana di atas 50 milyar, yakni Dompet Dhuafa Rp. 260.937.152.072, dan Rumah Zakat Rp. 244.421.903.469. Sehingga diharapkan kedua organisasi tersebut dapat mengontrol pengelolaan dana yang terhimpun dengan baik.

Dengan dilakukannya penelitian ini diharapkan akan diketahui variabel yang dapat ditingkatkan efisiensinya dan seberapa besar dana zakat yang dapat dihimpun dan disalurkan secara optimal.

\section{Pengertian dan Tujuan Pengelolaan Zakat}

Berdasarkan Undang-Undang Nomor 23 Tahun 2011 tentang Pengelolaan Zakat, yang dimaksud pengelolaan zakat adalah kegiatan yang meliputi perencanaan, pengorganisasian, pelaksanaan, dan pengawasan terhadap pendistribusian serta pendayagunaan zakat.

\footnotetext{
${ }^{11}$ Zusiana Elly Triantini, "Perkembangan Pengelolaan Zakat di Indonesia", Al-Ahwal, Vol. 3, No. 1 (2010), 90.

${ }^{12}$ Achmad Subianto, Ringkasan dan Bagaimana Membayar Zakat (Jakarta: Yayasan Bermula dari Kanan, 2009), 10.

${ }^{13}$ Pusat Bahasa Departeman Pendidikan Nasional, Kamus Besar Bahasa Indonesia (Jakarta: Pusat Bahasa, 2008), 472.

${ }^{14}$ Devi Megawati dan Fenny Trisnawati, "Penerapan PSAK 109 Tentang Akuntansi Zakat dan Infak/Sedekah pada BAZ Kota Pekanbaru”, Jurnal Penelitian Sosial Keagamaan, Vol. 17, No. 1 (Januari-Juni 2014), 84.

${ }^{15}$ Nina Doyle, "Buklet Organisasi yang Sehat dan Dapat Dipercaya (Buklet 1 dari 11 Seri Pengerahan Sumber Daya)" dalam http://keuanganlsm.com/etika-dalam-pencarian-dana/.
} 
Sedangkan tujuan dari pengelolaan zakat adalah untuk meningkatkan efektivitas dan efisiensi pelayanan dalam pengelolaan zakat, serta meningkatkan manfaat zakat untuk mewujudkan kesejahteraan masyarakat dan penanggulangan kemiskinan. ${ }^{16}$

\section{Pola Pengelolaan Zakat}

Zakat yang telah dikumpulkan oleh lembaga pengelola zakat, harus segera disalurkan kepada mustahiq sesuai dengan skala prioritas yang telah disusun dalam program kerja. Penyaluran zakat bisa dilakukan dengan dua cara, yaitu:

1. Pola tradisional (konsumtif)

Yaitu penyaluran bantuan dana zakat yang diberikan langsung kepada mustahiq tanpa disertai adanya target, kemandirian sosial, maupun kemadirian ekonomi (pemberdayaan). Dana zakat yang diterima mustahiq digunakan secara langsung untuk memenuhi kebutuhan sehari-hari.

2. Pola kontemporer (produktif)

Yaitu pola penyaluran dana zakat kepada mustahiq yang disertai dengan adanya target untuk merubah keadaan penerima dari kategori mustahiq menjadi kategori muzakki.

\section{Lembaga Amil Zakat}

Amil zakat adalah semua pihak yang melakuan pekerjaan-pekerjaan yang berkaitan dengan pengumpulan, penyimpanan, perlindungan, pencatatan, dan penyaluran harta zakat. Mereka diangkat oleh pemerintah yang berkuasa oleh masyarakat Islam setempat untuk memungut dan membagikan serta tugas-tugas lain yang berhubungan dengan zakat. ${ }^{17}$

Setelah mendapat pengukuhan, LAZ memiliki kewajiban sebagai berikut: ${ }^{18}$

1. Segera melakukan kegiatan sesuai dengan program kerja yang telah dibuat.

2. Menyusun laporan, termasuk laporan keuangan.

3. Mempublikasikan laporan keuangan yang telah diaudit melalui media.

4. Menyerahkan laporan kepada pemerintah.

\section{Tugas dan Fungsi Lembaga Amil Zakat}

Salah satu tugas penting dari lembaga amil zakat adalah melakukan sosialisasi tentang zakat kepada masyarakat secara terus menurus dan berkesinambungan, melalui berbagai forum dan media. Dengan sosialisasi yang baik dan optimal, diharapkan masyarakat muzakki akan semakin sadar untuk membayar zakat melalui lembaga zakat yang kuat, amanah, dan terpercaya. ${ }^{19}$

Lembaga amil zakat memiliki fungsi yang optimal sebagai pengelola zakat di Indonesia dalam menghimpun dan mendayagunakan dana zakat. Karena, yang menjadi tujuan awal usaha lembaga amil zakat adalah pengelolaan dan pendistribusian. Pengeolaan dalam arti mengusahakan agar dana zakat yang berhasil dihimpun dapat disalurkan ke pos-pos (așnäf alzakah) yang sesuai dengan yang dianjurkan dan ditetapkan oleh syariat Islam. Sedangkan

\footnotetext{
${ }^{16}$ Undang-Undang Republik Indonesia Nomor 23 Tahun 2011 tentang Pengelolaan Zakat.

${ }^{17}$ Malik Rahman, Zakat: 1001 Masalah dan Solusinya (Jakarta: Pustaka Cerdas, 2000), 201.

${ }^{18}$ Didin Hafidhuddin, Zakat dalam Perekonomian Modern (Jakarta: Gema Insani, 2002), 193.

${ }^{19}$ Ibid.
} 
pendistribusian termasuk juga pendayagunaan.

Lembaga amil zakat harus mampu merancang program yang sifatnya pendayagunaan agar dana zakat yang akan disalurkan kepada asnaf tidak habis sia-sia dan lebih produktif. Dalam hal ini jelas terlihat bahwa lembaga amil zakat memiliki peran strategis untuk meningkatkan ekonomi.

\section{Pengukuran Efisiensi pada Lembaga Amil Zakat}

Lembaga amil zakat merupakan salah satu jenis dari organisasi nirlaba yang tidak berorientasi pada pencarian laba melainkan sebuah wadah yang bertujuan untuk mensejahterakan kehidupan sosial. Bagi para stakeholder organisasi nirlaba seperti lembaga amil zakat, pengukuran efisiensi erat sekali dengan kinerja organisasi. Pengukuran kinerja dapat digunakan sebagai evaluasi atas akuntabilitas internal dan eksternal organisasi tersebut. Kinerja pada dasarnya adalah sebuah konsep multidimensi yang dapat berupa waktu, kualitas, inovasi, efisiensi, efektivitas, atau dimensi lain.

Meskipun OPZ berdasarkan aktivitas sosial, lembaga zakat perlu menjunjung tinggi profesionalisme, transparansi dan akuntabilitas dalam manajemennya. Termasuk dalam istilah ini, OPZ perlu beroperasi efektif dan efisien. Dalam sebuah efisiensi, pengukuran kinerja akan memberikan pijakan bagi manajemen untuk mengendalikan jalannya lembaga secara efektif. Bila sebuah lembaga menjalankan aktivitas tanpa melakukan pengukuran terhadap kinerja, maka lembaga tersebut tidak dapat melakukan perbaikan, meningkatkan pelayanannya.

Ukuran-ukuran efisiensi (kinerja) organisasi nirlaba seperti LAZ dapat berupa: ${ }^{20}$

1. Benefit, menyatakan ukuran keuangan dari nilai sosial yang dilekatkan pada jasa organisaisi. Penilaian keuangan dari benefit mencakup dua komponen, yaitu pengeluaran sosial dan peningkatan pendapatan masyarakat (dalam lembaga amil zakat yang dimaksud masyarakat adalah mustahiq).

2. Outcome, menyatakan ukuran non-keuangan dari manfaat sosial yang diberikan organisasi. Contohnya, jumlah mustahiq yang mengalami peningkatan pendapatan.

3. Output, menyatakan berbagai ukuran dari volume kegiatan tanpa memperhatikan apakah output tersebut mengarahkan organisasi pada outcome yang diharapkan. Contohnya, jumlah mustahiq yang diberdayakan.

4. Input, menunjukkan ukuran non-keuangan dari jenis-jenis sumber daya yang digunakan organisasi.

5. Cost, menunjukkan nilai keuangan dari semua sumber daya yang digunakan oleh organisasi untuk meningkatkan pelayanan jasanya.

\section{Metode Penelitian}

Objek dalam penelitian ini adalah lembaga amil zakat nasional (LAZNAS) yang sudah mendapat lisensi dari pemerintah sebagai LAZ nasional yang resmi dan boleh beroperasi dalam mengelola dana zakat, infaq dan sedekah di Indonesia, yaitu Dompet Dhuafa dan Rumah Zakat. Teknik pengumpulan data yang digunakan dalam penelitian ini berupa desk research yang dikenal juga dengan studi kepustakaan dan observasi.

Untuk mengidentifikasi variabel input dan output yang digunakan dalam lembaga zakat,

\footnotetext{
${ }^{20}$ Joelani, Pengukuran Kinerja Organisasi Lembaga (Depok: FEUI, 1994), 79.
} 
penelitian ini menggunakan metode pendekatan produksi. Pendekatan produksi mengukur bagaimana kinerja lembaga zakat dalam pengelolaan biaya guna menghasilkan penerimaan dan penyaluran dana ZIS yang efisien.

Penelitian ini menggunakan metode Data Envelopment Analysis (DEA) ini menggunakan variabel input dan output. Variabel input yang digunakan adalah total aset, biaya sosialisasi dan biaya operasional kantor. Sedangkan variabel output yang digunakan adalah jumlah penerimaan dana zakat dan jumlah penyaluran dana zakat.

\section{Metode Analisis Data}

Penelitian ini menggunakan Data Envelopment Analysis (DEA) yang merupakan metode yang telah distandarisasi sebagai alat untuk mengukur kinerja suatu aktifitas unit, di mana proses pengolahannya menggunakan perangkat lunak WDEA. Penelitian ini menggunakan asumsi Constants Return to Scale (CRS), di mana setiap penambahan satu input akan diikuti oleh penambahan satu output. Selain itu penelitian ini juga menggunakan pendekatan produksi. Pendekatan produksi dipilih untuk mengukur bagaimana kinerja OPZ dalam pengelolaan biaya guna menghasilkan penerimaan dana ziswaf serta penyaluran dana ziswaf yang efisien.

\section{Model Pengukuran Efisiensi Teknis}

Efisiensi teknis lembaga amil zakat dapat diukur dengan menghitung rasio antara output dan inputnya. DEA akan menghitung LAZ yang menggunakan input $n$ untuk menghasilkan output $m$ yang berbeda: ${ }^{21}$

$$
\text { Es }=\frac{\sum_{i=1}^{m_{i}} \operatorname{Ui~Ys}}{\sum_{j=1}^{n_{j=1} V j X j s}}
$$

Di mana:

Es $=$ Efisiensi LAZ $\mathrm{s}$

$\mathrm{m}=$ output LAZ $\mathrm{s}$ yang diamati

$\mathrm{n}$ = input LAZ $\mathrm{s}$ yang diamati

Ys = jumlah output i yang dihasilkan LAZ s

$\mathrm{Xjs}=$ jumlah input $\mathrm{j}$ yang dihasilkan LAZ $\mathrm{s}$

$\mathrm{Ui}=$ jumlah bobot output yang dihasilkan oleh LAZ $\mathrm{s}$

$\mathrm{Vj}=$ jumlah bobot input yang diberikan oleh LAZ s, dan i dihitung dari $1 \mathrm{ke} \mathrm{m}$ serta $\mathrm{j}$ dihitung dari $1 \mathrm{ke} n$.

Persamaan di atas menunjukkan adanya penggunaan satu variabel input dan satu output. Rasio efisiensi (Es), kemudian dimaksimumkan dengan kendala sebagai berikut:

$$
\begin{aligned}
& \text { Es }=\frac{\sum_{i=1}^{m} U i Y i s}{\sum_{i=1}^{n} V j X j s} \leq 1: \mathrm{r}=1, \ldots \mathrm{N} \\
& \text { Di mana Ui dan } \mathrm{Vj} \geq 0
\end{aligned}
$$

\footnotetext{
${ }^{21}$ Adrian Sutawijaya dan Etty Puji Lestari, "Efisiensi Teknik Perbankan Indonesia Pascakrisis Ekonomi: Sebuah Studi Empiris Penerapan Model DEA”, Jurnal Ekonomi Pembangunan, Vol. 10, No. 1 (2009), 55-58.
} 
Persamaan di atas, di mana $\mathrm{N}$ mewakili jumlah LAZ dalam sampel dan $\mathrm{r}$ merupakan jenis LAZ yang dijadikan sampel dalam penelitian. Pertidaksamaan pertama menjelaskan bahwa adanya rasio untuk UKE lain tidak lebih dari 1, sementara pertidaksamaan kedua berbobot non-negatif (positif). Angka rasio akan bervariasi antara 0 sampai dengan 1. LAZ dikatakan efisien apabila memiliki angka rasio mendekati 1 atau 100 persen, sebaliknya apabila mendekati 0 menunjukkan efisiensi LAZ yang semakin rendah. Pada DEA, setiap LAZ dapat menentukan bobotnya masing-masing dan menjamin bahwa pembobotnya yang dipilih akan menghasilkan kinerja yang terbaik. ${ }^{22}$

Metode analisis pada persamaan 1 dan 2 juga dapat dijelaskan bahwa efisiensi sejumlah LAZ yang UKE (n). Setiap LAZ menggunakan $\mathrm{n}$ jenis input untuk menghasilkan $\mathrm{m}$ jenis output, apabila Xjs merupakan jumlah input j yang digunakan oleh LAZ sedangkan Yis $>0$ merupakan jumlah output I yang dihasilkan oleh LAZ. Variabel keputusan (decision variable) dari penjelasan tersebut adalah bobot yang harus diberikan pada setiap input dan output LAZ. Vj merupakan bobot $\mathrm{n}$ yang diberikan pada input $\mathrm{j}$ oleh LAZ dan Ui merupakan bobot yang diberikan pada output i oleh LAZ, sehingga vj dan ui merupakan variabel keputusan. $^{23}$

Nilai variabel ini ditentukan melalui interaksi program linear, kemudian diformulasikan pada sejumlah s program linear fraksional. Satu formulasi program linear untuk setiap LAZ dalam sampel. Fungsi tujuan dari setiap program linear fraksional tersebut adalah rasio dari output tertimbang dibagi rasio input tertimbang dari LAZ. ${ }^{24}$

Beberapa program linear ditransformasikan ke dalam program ordinary liniear secara primal atau dual, sebagai berikut:

$$
\begin{aligned}
& \text { Memaksimumkan Es }=\sum_{i=1}^{m} U i \text { Yis } \\
& \text { Fungsi batasan atau kendala: } \\
& \sum_{i=1}^{m} \text { Ui Yir }-\sum_{j=1}^{n} \text { Vj Yjr } \leq 0 ; r=1, \ldots N \\
& \sum_{j=1}^{n} \text { Vj Xjs }=1
\end{aligned}
$$

Di mana Ui dan $\mathrm{Vj} \geq 0$ dan Uo merupakan penggal yang dapat bernilai positif atau negatif. Efisiensi pada masing-masing LAZ dihitung menggunakan programisasi linear dengan memaksimalkan jumlah output yang dibobot dari LAZ s. Kendala jumlah input yang dibobot harus sama dengan satu untuk LAZ s, sedangkan kendala untuk semua LAZ, yaitu output yang dibobot dikurangi jumlah input yang dibobot harus kurang atau sama dengan 0 . Hal ini berarti bahwa semua LAZ akan berada atau di bawah referensi kinerja frontier yang merupakan garis lurus yang memotong sumbu origin. ${ }^{25}$

\footnotetext{
22 Ibid.

${ }^{23}$ Harjum Muharram dan Rizki Pusvitasari, “Analisis Perbandingan Efisiensi Bank Syariah di Indonesia dengan Metode Data Envelopment Analysis (Periode tahun 2005)", Jurnal Ekonomi dan Bisnis Islam, Vol. II, No. 3 (2007), 164.

${ }^{24}$ Ibid.

25 Nopirin Insukindro, Laporan Akhir Pengukuran Efisiensi Relatif Pelayanan Kantor Cabang Pegadaian (Yogyakarta: Penelitian dan Pengembangan Manajemen (PPM) Fakultas Ekonomi Universitas Gadjah Mada, 2009), 20.
} 
Beberapa program linier ditransformasikan ke dalam program ordinary liniear secara primal atau dual, sebagai berikut:

$$
\begin{aligned}
& \text { Maksimumkan Es }=\sum_{i=1}^{m} \text { Ui yis }+V o \\
& \text { Fungsi batasan atau kendala: } \\
& \sum_{i=1}^{m} \text { Ui Yir }-\sum_{j=1}^{n} V j \text { Yj } \mathrm{r} \leq 0: \mathrm{r}=1, \ldots \mathrm{N} \\
& \sum_{j=1}^{n} \operatorname{Vj} \text { Xjs }=1
\end{aligned}
$$

Dimana Ui dan $\mathrm{Vj} \geq 0$ Dan Uo merupakan penggal yang dapat bernilai positif atau _able_ve.

\section{Tingkat Efisiensi kedua Lembaga Pengelola Zakat Periode 2012-2016}

Suatu DMU akan bernilai efisien apabila memiliki skor efisien sebesar 100\%. Infisiensi terjadi apabila skor yang diperoleh kurang dari 100\%. Pada penelitian ini, perhitungan efisiensi diolah dengan software WDEAP. Dari hasil olah data yang dilakukan, didapat skor efisiensi dari kedua lembaga yang ditunjukkan pada tabel di bawah ini:

Tabel 1.2. Tingkat Efisiensi kedua Lembaga Pengelola Zakat

\begin{tabular}{|c|c|c|}
\hline Tahun & Dompet Dhuafa & Rumah Zakat \\
\hline $\mathbf{2 0 1 2}$ & $100 \%$ & $100 \%$ \\
\hline $\mathbf{2 0 1 3}$ & $100 \%$ & $100 \%$ \\
\hline $\mathbf{2 0 1 4}$ & $100 \%$ & $100 \%$ \\
\hline $\mathbf{2 0 1 5}$ & $78,71 \%$ & $100 \%$ \\
\hline $\mathbf{2 0 1 6}$ & $64,33 \%$ & $100 \%$ \\
\hline Rata-rata & $88,6 \% \%$ & $100 \%$ \\
\hline
\end{tabular}

Sumber: diolah penulis menggunakan WDEAP

Dari tabel di atas dapat diketahui bahwa tingkat efisiensi kedua lembaga pengelola zakat dari tahun 2012-2016. Dalam pelaksanaanya kedua lembaga pengelola zakat tersebut sudah menjalankan fungsinya sebagai lembaga sosial dengan baik atau efisien.

Dilihat dari tabel di atas, rumah zakat sudah cukup efisien dalam mengelola input untuk menghasilkan output dibuktikan dengan skor efisiensi, yaitu 100\%. Namun berbeda dengan Dompet Dhuafa, pada tahun 2015 dan 2016 masih belum maksimal dalam mengelola input untuk menghasilkan output. Pada tahun 2015, tingkat efisiensi Dompet Dhuafa sebesar $78,71 \%$. Artinya masih terdapat inefisiensi sebesar 21,29\%. Berberda pada tahun 2016 tingkat efisiensi Dompet Dhuafa menurun di angka 64,33\%. Artinya masih terdapat inefisiensi pada lembaga Dompet Dhuafa sebesar 35,67\%. Jika dilihat dari rata-rata skor efisiensi dalam periode pengamatan tersebut maka Rumah Zakat lebih efisiensi dari pada Dompet Dhuafa, yaitu memiliki skor $100 \%$.

Dari perhitungan efisiensi yang sudah dilakukan, selain skor efisiensi secara umum, terdapat juga skor efisiensi per variabel yang membentuk efisiensi general. Jumlah variabel nyata yang efisien ditunjukkan dengan angka aktual dan angka proyeksi pada analsisis 
variabel. Angka aktual merupakan angka input dan output yang dimiliki, sedangkan angka proyeksi merupakan angka yang dapat dicapai oleh DMU dari perhitungan DEA.

\section{Analisis Faktor-Faktor Penyebab Inefisiensi Lembaga Amil Zakat}

Dompet Dhuafa mengalami inefisiensi selama dua tahun berturut-turut. Pada tahun 2015 Dompet Dhuafa mengalami inefisiensi sebesar 21,29\%, tahun 2016 angka inefisiensi semakin membesar, yaitu 35,67\%. Rata-rata inefisiensi selama lima tahun adalah 11,4\%.

Inefisiensi ini biasa disebabkan oleh pemborosan biaya atau tidak seimbangnya jumlah dana-dana dalam beberapa variabel yang diolah untuk menghitung tingkat efisiensi. ${ }^{26}$ Sesuai dengan penjelasan sebelumnya pada tabel efisinsi teknis, seluruh variabel input dan satu variabel output dari Dompet Dhuafa pada tahun 2015 dan 2016 tidak sesuai target perhitungan efisiensi DEA, yaitu sebesar 21,29\% dan 35,67\%. Variabel yang menyebabkan terjadinya inefisiensi tersebut di antaranya total aset dan biaya sosialisasi yang melebihi target efisiensi, penerimaan dan penyaluran dana zakat yang masih kurang dari target efisiensi maksimal.

Faktor yang mempengaruhi inefsiensi secara teknis adalah kurang maksimalnya penggunaan kapasitas input menunjukkan bahwa penambahan input tidak dapat menambah output yang sama besarnya atau lebih besar. Oleh karena itu, diperlukan pengurangan input hingga mencapai titik Constant Returnto Scale. ${ }^{27}$

Metode Data Envelopment Analysis (DEA) memiliki beberapa keunggulan, salah satunya menghasilkan menghasilkan nilai efisiensi relatif untuk setiap unit kegiatan ekonomi, yaitu dengan menampilkan tingkat perbaikan yang dibutuhkan oleh masing-masing unit kegiatan ekonomi untuk mencapai tingkat efisiensi maksimal.

\section{Kesimpulan}

Berdasarkan hasil analisis tingkat efisiensi lembaga amil zakat menggunakan metode Data Envelopment Analysis (DEA) periode 2012-2016 dengan pendekatan produksi dalam menentukan variabel input dan output. Dalam periode 2012-2016 tingkat efisiensi Rumah Zakat mencapai $100 \%$ atau senilai dengan 1 . Hal ini menunjukan bahwa Rumah Zakat sudah efisien secara maksimal di setiap tahunnya. Sedangkan pada Dompet Dhuafa, terjadi tingkat efisiensi yang fluktuatif setiap tahunnya. Di tahun 2012,2013 dan 2014 mencapai tingkat efisiensi maksimal sebesar 100\%, sedangkan pada tahun 2015 mengalami penurunan inefisiensi pada angka 78,71\% dan melakukan inefisiensi sebesar 21,29\%. Diikuti pada tahun 2016 Dompet Dhuafa kembali menurun tingkat efisiensinya pada angka 64,33\%. Sedangkan tingkat efisiensi rata-rata tahunannya sebesar $88,6 \%$ dan rata-rata inefisiensi sebesar $11,4 \%$.

\footnotetext{
26 Indah Susilowati dkk, Pengukuran Efisiensi Melalu Data Envelopment Analysis (DEA) (Semarang: FE UNDIP, 2004), 85.

${ }^{27}$ N. Akbar, "Analisis Efisiensi Organisasi Pengelola Zakat Nasional dengan Pendekatan Data Envelopment Analysis", Tazkia Islamic Finance and Business Review, Vol. 4, No. 2 (2009), 760-784.
} 


\section{Daftar Rujukan}

Akbar, N. "Analisis Efisiensi Organisasi Pengelola Zakat Nasional dengan Pendekatan Data Envelopment Analysis", Tazkia Islamic Finance and Business Review, 4 (2), 2009.

Badan Pusat Statistik. Persentase Penduduk Miskin di Indonesia 2018. Jakarta Pusat: Badan Pusat Stastistik, 2018.

Bariyah, Nurul. Total Quality Management Zakat. Jakarta: Wahana Kardofa FAI UMJ, 2012.

Badan Amil Zakat Nasional. Outlook Zakat Indonesia 2017. Jakarta: Pusat Kajian Strategis Baznas, 2016.

Badan Amil Zakat Nasional. Outlook Zakat Indonesia 2019. Jakarta: Pusat Kajian Strategis Baznas, 2019.

Badan Amil Zakat Nasional. Dokumen Statistik BAZNAS 2017. Jakarta: BAZNAS, 2017.

Beik, Irfan Syauqi. "Analisis Peran Zakat dalam Mengurangi Kemiskinan: Studi Kasus Dompet Dhuafa”. Jurnal Zakat \& Empowering: Jurnal Pemikiran dan Gagasan. Vol. II, 2009.

Coelli, TJ. A Guide to DEAP Version 2.1: A Data Envelopment Analysis (Computer) Program. Armidale: Department of Econometrics, University of New England Australia, 1996.

Departemen Pendidikan Nasional. Kamus Besar Bahasa Indonesia, Cetakan IV. Jakarta: Gramedia Pustaka Utama, 2008.

Dompet Dhuafa. https://www.dompetdhuafa.org/about. Diakses 12 November 2018.

Fakhruddin. Fiqh dan Manajemen Zakat di Indonesia. Malang: UIN-Malang Press, 2008.

Hafidhuddin, Didin. Zakat dalam Perekonomian Modern. Jakarta: Gema Insani, 2002.

Institut Management Zakat. Indonesian Zakat and Development Report. Ciputat: IMZ, 2010.

Insukindro, Nopirin, dkk. Laporan Akhir Pengukuran Efisiensi Relatif Pelayanan Kantor

Cabang Pegadaian. Yogyakarta: Penelitian dan Pengembangan Manajemen (PPM) Fakultas Ekonomi Universitas Gadjah Mada, 2000.

Joelani. Pengukuran Kinerja Organisasi Lembaga. Depok: FEUI, 1994.

Kustiawan, Teten, dkk. Pedoman Akuntansi Amil Zakat: Implementasi Penyusunan Laporan Keuangan Berbasis PSAK 109. Jakarta: Forum Zakat, 2007.

Lestari, Alfi. "Efisiensi Kinerja Keuangan Badan Amil Zakat Daerah (BAZDA): Pendekatan Data Envelopment Analysis (DEA)". Jurnal Ekonomi dan Studi Pembangunan. Vol. 16, No. 2, 2015.

Megawati, Devi, dan Fenny Trisnawati. "Penerapan PSAK 109 Tentang Akuntansi Zakat dan Infak/Sedekah pada BAZ Kota Pekanbaru”. Jurnal Penelitian Sosial Keagamaan. Vol. 17, No. 1 Januari-Juni, 2014.

Miller. S.M., and Noulas. A. G. "The Technical Efficiency of Large Bank Production". Journal of Banking and Finance (20), 1996.

Muharram, Pusvitasari. "Analisis Perbandingan Efisiensi Bank Syariah di Indonesia dengan Metode Data envelopment Analysis". Jurnal Ekonomi dan Bisnis Islam. Vol. II, No. 3, 2005.

Norazlina A. W. and Abdul R. A. R. "Efficiency of Zakat Institutions in Malaysia: An Application of Data Envelopment Analysis". Journal of Economic Cooperation and Development. 33 (1), 2012. 
Pusat Bahasa Departeman Pendidikan Nasional. Kamus Besar Bahasa Indonesia. Jakarta: Pusat Bahasa, 2008.

Rahman, Malik. Zakat: 1001 Masalah dan Solusinya. Jakarta: Pustaka Cerdas, 2000.

Rumah Zakat. https://www.rumahzakat.org/en/tentang-kami/. Diakses 12 November 2018.

Rustyani, Rosyidi. "Measurement of Efficiency and Productivity of Zakat Institutions in Indonesia using Data Envelopment Analysis and the Malmquist Productivity Index". International Journal of Zakat. Vol. 3 (3), 2018.

Samsubar, Saleh. Metode Data Envelopment Analysis. Yogyakarta: PAU-FE UGM, 2000.

Sudewo, Eri. Manajemen Zakat: Tinggalkan 15 Tradisi Terapkan 4 Prinsip Dasar. Ciputat: Institut Manajemen Zakat, 2004.

Suprayitno, Eko. "Pengaruh Zakat Terhadap Variabel Makro Ekonomi Indonesia: Studi pada Perekonomian Indonesia Tahun 2000". Tesis--Universitas Gadjah Mada Yogyakarta, 2004.

Susilowati, Indah, dkk. Modul Perkuliahan: Pengukuran Efisiensi Melalu Data Envelopment Analysis (DEA). Semarang: FE UNDIP, 2004.

Subianto, Achmad. Ringkasan dan Bagaimana Membayar Zakat. Jakarta: Yayasan Bermula dari Kanan, 2009.

Triantini, Zusiana Elly. "Perkembangan Pengelolaan Zakat di Indonesia". Al-Ahwal. Vol. 3, No. 1, 2010.

Tuasikal, Muhammad Abduh. Panduan Mudah tentang Zakat. Yogyakarta: Pustaka Muslim, 2014

Utsaimin, Muhammad ibn Shalih. Fatâwā fī Ahkämi al-Zakah, Terj. Ghazali Mukri. Solo: alQowam, 2011. 